\title{
PERAN PEMASARAN Dalam KEGIATAN USAHA Pada MASYARAKAT Di DESA JATIBARU CIKAMPEK
}

\author{
Oleh: \\ Fadli Rasam \\ Ani Interdiana Candra Sari \\ Program Studi Pendidikan Ekonomi \\ Fakultas Ilmu Pendidikan dan Pengetahuan Sosial \\ Universitas Indraprasta PGRI
}

Email:

fadrasam@gmail.com

\begin{abstract}
ABSTRAK
Pemasaran merupakan faktor penting dalam perkembangan perusahaan. Pemasaran yang baik dilakukan lewat produk (productt), harga (price), tempat/distribusi (place), dan promosi (promotion). Kurangnya pengetahuan terhadap selera konsumen yang berubah-ubah atau dinamis, serta tidak efektifnya strategi pemasaran yang diterapkan akan berdampak kurang baik pada pencapaian target pasar. Tujuan yang ingin dicapai dari penelitian ini adalah ingin memperoleh jawaban secara empirik dan mengetahui Peran Pemasaran dalam Kegiatan Usaha pada Masyarakat di Desa Jatibaru, Cikampek. Metoda penelitian yang diterapkanya itu metode kualitatif. Sesuai dengan fokus penelitian, maka untuk mendapatkan data peran pemasaran sumber datanya diperoleh dari informan melalui angket dan wawancara. Ditinjau dari segi produk (productt), bahwa produk yang dinginkan masyarakat adalah produk yang sesuai kebutuhan masyarakat, berkualitas, memiliki desain yang menarik, produk yang dihasilkan ramah lingkungan, dan mudah diingat masyarakat. Ditinjau dari segi harga (price), masyarakat menginginkan harga yang sesuai dengan kualitas, tejangkau setiap lapisan masyarakat, dan harga mampu bersaing. Ditinjau dari tempat (place) masyarakat menginginkan produk yang akan dibeli mudah didapatkan, mudah diakses, jangkauan tempat terbatas. Ditinjau dari promosi, masyarakat menginginkan pemasaran dilakukan dengan cara bagaimana peran pemerintah dalam mempromosikan sebuah produk, door to door, secara online dan personal selling.
\end{abstract}

Kata Kunci: Peran Pemasaran, Bauran Pemasaran, masyarakat 


\section{A. PENDAHULUAN}

Majunya perekonomian Indonesia sekarang ini ditandai dengan pertumbuhan industry yang begitu pesat. Dunia bisnis terus mengalami perkembangan yang sangat signifikan, dimana setiap perusahaan berlomba-lomba melebarkan sayap mereka atau dengan kata lain melakukan ekspansi bisnis dengan melakukan berbagai macam strategi seperti melakukan promosi atau melakukan berbagai macam inovasi produk demi memperkenalkan dan menjual produk mereka di daerah-daerah yang belum mereka jangkau. Pemasaran yang baik tentang bagaimana barang atau jasa hasil produksi dapat dikenal dan dibeli oleh masyarakat, dan pemasaran yang tepat itu bukanlah kebetulan, melainkan hasil dari eksekusi dan perencanaan yang cermat. Praktik Pemasaran harus terusmenerus ditingkatkan dan diperbaharui, hal ini tentunya tidak terlepas dari kebutuhan dan keinginan konsumen tersebut. Perusahaan untuk mencapai pemasaran yang baik tentunya harus merencanakan produk dan jasa terlebih dahulu, menentukan harga, mempromosikan dan mendistribusikan barang dan jasa pada konsumen pada akhirnya.

Pemasaran mempunyai peranan yang penting dalam masyarakat karena pemasaran menyangkut berbagai aspek kehidupan, termasuk bidang ekonomi dan sosial. Pemasaran berarti mengalirkan produk dari produsen ke konsumen, maka pemasaran akan menciptakan lapangan kerja yang penting bagi masyarakat. Perlu diketahui bahwa biaya pemasaran dibeberapa perusahaan mempunyai porsi yang hampir sama dengan biaya produksi. Mengapa demikian, hal ini berkaitan dengan pengenalan produk yang telah diproduksi kepada konsumen/masyarakat. Pemasaran tidak selalu diartikan dengan menjual produk secara langsung kepada konsumen namun pada era sekarang banyak cara dilakukan. Penggunaan media advertensi seperti spanduk, banner, baliho, iklan TV, iklan radio dan lain-lain adalah cara lain melakukan kegiatan pemasaran. Peranan pemasaran dalam memenuhi kebutuhan dan keinginan manusia setiap manusia selalu berusaha memenuhi semua kebutuhannya dengan mengkonsumsi produk yang ada.

Pemenuhan kebutuhan tersebut dengan melihat manfaat dan kegunaannya. Manfaat atau kegunaan dapat dilihat dari bentuk, tempat, waktu dan kepemilikan. Fungsi pemasaran juga mempunyai peranan yang sangat penting dalam meningkatkan daya guna suatu barang, yang tadinya kurang berarti di suatu tempat dan akan menjadi tinggi nilainya di tempat lain. Dengan meningkatnya dayaguna suatu barang maka secara otomatis akan memenuhi kebutuhan dan keinginan manusia terhadap produk/barang tersebut. Di era modern ini dengan semakin tingginya taraf hidup sosial suatu masyarakat maka semakin banyak tingkat pilihan masyarakat dalam memenuhi kebutuhannya. Oleh karena itu, sangat dibutuhkan pemasaran agar masyarakat dapat mengetahui dan mengenali berbagai macam produk sejenis dan tentunya dengan manfaatnya masing-masing. Peranan Pemasaran Dalam Mengalirnya Produk Dari Produsen Ke Konsumen pada dasarnya adalah kegiatan pemasaran yang menyangkut 2 hal, yaitu aliran fisik barang dan aliran kegiatan transaksi barang tersebut. 
Aliran transaksi dimulai dari penjualan barang dari pabrik kepada pedagang besar, kemudian dari pedagang besar dijual kepada agen, dari agen dijual kembali kepada toko-toko di pasar dan akhirnya kepada konsumen. Dari kegiatan tersebut banyak pihak yang berperan pula yaitu sektor transportasi (darat dan laut), kemudian jasa sewa gudang dan pihak perbankan maupun pihak asuransi.

Dari masalah yang ditemui diatas, maka peneliti akan melakukan studi komprehensif untuk menganalisis "Peran Pemasaran dalam Kegiatan Usaha pada Masyarakat di Desa Jatibaru, Cikampek."

\section{B. TINJAUAN PUSTAKA}

\section{Pengertian Peranan Pemasaran}

Sebagian orang yang menganggap pemasaran sama dengan penjualan atau periklanan, padahal periklanan dan penjualan hanyalah bagian dari pemasaran. Pemasaran perlu dipahami dalam arti yang lebih luas, yaitu suatu proses sosial dan manajerial yang membuat individu dan kelompok memperoleh apa yang mereka butuhkan dan inginkan lewat penciptaan dan pertukaran timbal balik produk dan nilai dengan orang lain. Dalam (Kotler \& Keller, 2009, hal. 5) Pemasaran merupakan bagian dari fungsi organisasi yang merupakan serangkaian tindakan (proses) dalam menciptakan lalu berkomunikasi serta memberikan suatu nilai pada pelanggan dalam mengelola hubungan dengan hal-hal yang membuat keuntungan bagi organisasi serta pihak yang mempunyai kepentingan untuk organisasi. Menurut (Tjiptono, 2008, hal. 5), Pemasaran dalam kegunaannya mempunyai pengaruh yang besar terhadap lingkungan eksternal, meskipun pada prinsipnya perusahaan memiliki pengaturan yang terbatas kepada lingkup eksternal tersebut.

Menurut (Kotler \& Keller, 2009, hal. 19) manajemen pemasaran terjadi pada saat pihak yang satu dalam kegiatan pertukaran kegiatan yang mempunyai kemampuan berfikir dengan cara merespon hal-hal yang diinginkan oleh pihak pihak yang lain. Maka dari itu kiranya perlu melihat manajemen pemasaran merupakan suatu ilmu dan seni dalam memilah dan memilih segmentasi pasar dalam mencapai sasaran, mendapatkan, mempertahankan serta meningkatkan kuantitas pelanggan dengan cara menciptakan, menyampaikan komunikasi dengan nilai yang terbaik.

Menurut (Kotler \& Keller, 2009, hal. 36), inti pemasaran adalah memenuhi kebutuhan konsumen dan melengkapi keinginan yang diperlukan oleh konsumen. Target yang menjadi dari sasaran ini adalah menyampaikan nilai pada pelanggan dalam menghasilkan keuntungan. Untuk menciptakan dan menyampaikan nilai tersebut dapat melalui fase-fase berikut dalam memilih nilai, fase menyediakan dan menyiapkan nilai, fase mengkomunikasikan dan menyampaikan nilai-nilai kepada pelanggan.

(Kotler \& Keller, 2009, hal. 36) menjelaskan mengenai urutan dalam penciptaan dan menghantarkan penyampaian pada nilai melalui tiga fase yaitu:

a. Fase dalam memilihkan nilai, menyampaikan "pekerjaan rumah" pemasaran dapat dilakukan sebelum produk-produk yang dibuat oleh staf pemasaran 
harus mengkategorikan pasar, memilah dan memilih tujuan pada pasar yang tepat dan menumbuhkan terhadap penawaran positioning pada nilai (STP).

b. Fase menyediakan nilai, produsen harus mampu menentukan dan menetapkan fitur yang berkaitan pada produk tertentu, harga dan distribusi.

c. Fase mengomunikasikan nilai, dengan mendayagunakan dan memaksimalkan tenaga penjualan (sales), promosi penjualan, iklan dan sarana komunikasi lain untuk mengumumkan dan mempromosikan produk.

Jadi pemasaran adalah bagaimana memuaskan kebutuhan pelanggan. Jika pemasar memahami kebutuhan pelanggan dengan baik, mengembangkan produk yang mempunyai nilai superior dan menetapkan harga, mendistribusikan dan mempromosikan produknya dengan efektif, produk-produk tersebut akan terjual dengan mudah.

Penjual dan pembeli dihubungkan oleh empat alur. Penjual memberikan barang atau jasa dan komunikasi (promosi) kepada pasar dan sebagai imbalannya penjual menerima uang dan informasi (sikap, data penjualan, dan sebagainya). Lingkaran paling dalam memperlihatkan suatu pertukaran uang dengan barang atau jasa, sedangkan lingkaran luar menunjukkan pertukaran informasi. Alur system pemasaran sederhana dapat dilihat pada Gambar 2.1

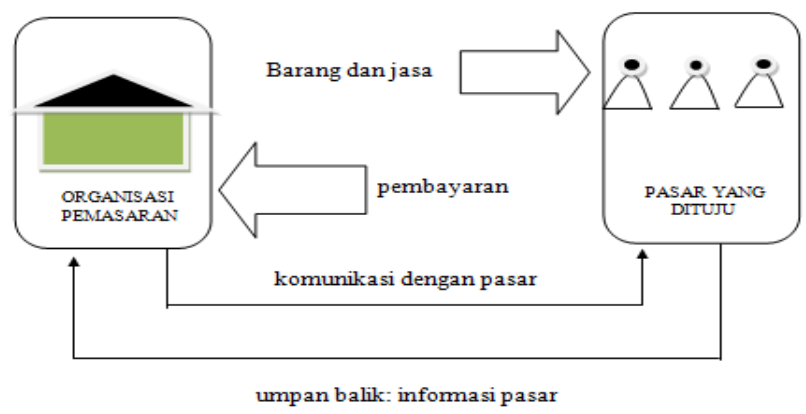

Gambar 1

Sistem Pemasaran Sederhana

Sebagian besar orang bisnis menggunakan istilah pasar secara informal untuk mencakup beragam pengelompokan pelanggan. Mereka membicarakan tentang pasar kebutuhan (seperti pasar pencari diet), pasar produk (seperti pasar sepatu), pasar demografis (seperti pasar remaja), dan pasar geografis (seperti pasar Asia). Atau mereka memperluas konsep tersebut agar mencakup pengelompokan non-pelanggan, seperti pasar pemberi suara, pasar tenaga kerja, dan pasar pemberi sumbangan.

\section{Bauran Pemasaran (Marketing Mix)}

(Assauri, 2011) menjelaskan bahwa bauran pemasaran merupakan suatu unsur dalam bagian strategi pemasaran yang terpusat adalah strategi bauran pemasaran yang merupakan strategi yang dijalankan oleh perusahaan, yang berkaitan erat dengan penentuan bagaimana cara perusahaan-perusahaan menyajikan penawaran produk pada segmen pasar tertentu, yang merupakan 
sasaran pasarnya. Bauran pemasaran rangkaian sarana pemasaran taktis terpadu yang dapat dikendalikan (produk, harga, tempat, dan promosi) untuk mengetahui respon pasar sasaran yang diinginkan oleh perusahaan. Menurut (Machfoedz, 2005) menjelaskan bahwa Marketing Mix adalah himpunan variabel yang dikuasai dan dapat digunakan oleh manajer pemasaran untuk menarik konsumen guna mempengaruhi penjualan atau pendapatan perusahaan.

Bauran pemasaran menurut Kotler yang dialih bahasakan oleh (Molan, 2007, hal. 17) adalah seperangkat alat pemasaran yang digunakan oleh perusahaan untuk terus menerus mencapai tujuan pemasarannya di pasar sasaran.

(Saladin, 2006, hal. 3) menjelaskan bahwa bauran pemasaran (marketing mix) adalah serangkaian dari variabel pemasaran yang dikuasai oleh pemasaran dan digunakan untuk mencapai tujuan dalam pasar sasaran, sehingga bauran pemasaran adalah sekumpulan variabel yang terkendali.

Marketing mix digunakan oleh pemasar agar produknya dapat memasuki pasar sasaran atau target market. Bauran pemasaran terdiri dari:

1. Produk yaitu terdiri atas keragaman produk, kualitas, desain, fitur, merek, kemasan, ukuran, dan garansi.

2. Harga yaitu terdiri dari daftar harga, diskon, promo, jangka pembayaran, dan syarat kredit.

3. Lokasi yaitu terdiri atas saluran distribusi, cangkupan, pengelompokan, lokasi, penyimpanan, dan trasnportasi.

4. Promosi yaitu terdiri dari atas promosi, penjualan, iklan, tenaga penjual, public relation, penjualan langsung.

\section{Produk (Productt)}

(Tjiptono, 2008, hal. 95) menjelaskan bahwa produk merupakan segala sesuatu yang dapat ditawarkan produsen untuk diperhatikan, dicari, dibeli, digunakan atau dikonsumsi pasar sebagai pemenuhan kebutuhan atau keinginan pasar yang bersangkutan. Produk yang ditawarkan meliputi barang fisik seperti sepeda motor, komputer, televisi sedangkan produk jasa meliputi restoran, penginapan dan transportasi. Produk bisa berupa manfaat tangible maupun intangible yang dapat memuaskan pelanggan. Produk secara konseptual, yaitu pemahaman subyektif dari produsen atas sesuatu yang bisa ditawarkan sebagai usaha untuk mencapai tujuan organisasi melalui pemenuhan kebutuhan dan keinginan konsumen sesuai dengan kompetensi dan kapasitas organisasi serta daya beli pasar. Produk yang sesuai kebutuhan masyarakat, berkualitas, memiliki desain yang menarik, produk yang dihasilkan ramah lingkungan, dan mudah diingat masyarakat.

\section{Harga}

(Assauri, 2011, hal. 223) mendefinisikan harga merupakan satu-satunya unsur marketing mix yang menghasilkan penerimaan penjualan, sedangkan unsur lainnya hanya unsur biaya saja. Harga bisa diungkapkan dengan berbagai istilah misalnya iuran, tarif, sewa, bunga, premium, komisi, upah, gaji, honorarium, SPP dan sebagainya. Dari sudut pandangan pemasaran, harga merupakan satuan 
moneter atau ukuran lainnya (termasuk bunga dan jasa lainnya) yang ditukarkan agar memperoleh hak kepemilikan atau penggunaan suatu barang atau jasa (Tjiptono, 2008). Masyarakat menginginkan harga yang sesuai dengan kualitas, tejangkau setiap lapisan masyarakat, dan harga mampu bersaing.

\section{Lokasi}

(Tjiptono, 2008, hal. 185) mendefinisikan secara garis besar, pendistribusian dapat diartikan sebagai kegiatan pemasaran yang berusaha memperlancar dan mempermudah penyampaian barang dan jasa dari produsen kepada konsumen, sehingga penggunaannya sesuai dengan yang diperlukan (jenis, jumlah, harga, tempat, dan saat dibutuhkan). Dengan kata lain proses distribusi merupakan aktivitas pemasaran yang mampu: (1) Menciptakan nilai tambah produk melalui fungsi-fungsi pemasaran yang dapat merealisasikan kegunaan bentuk, tempat, waktu dan kepemilikkan: (2) Memperlancar arus saluran pemasaran secara fisik dan non fisik. Yang dimaksd dengan arus pemasaran adalah aliran kegiatan yang terjadi diantara lembaga-lembaga pemasaran yang terlibat didalam proses pemasaran. Arus pemasaran meliputi barang fisi, arus kepemilikan, arus informasi, arus promosi, arus negoisasi, arus pembayaran, arus pendanaan, arus penanggung risiko dan arus pemesanan. Masyarakat menginginkan produk yang akan dibeli mudah didaptkan, mudah diakses, jangkauan tempat terbatas.

\section{Promosi}

Promosi merupakan salah satu faktor penentu keberhasilan suatu program pemasaran. Promosi merupakan cara khusus dari iklan pribadi, promosi penjualan dan hubungan masyarakat yang dipergunakan perusahaan untuk tujuan iklan dan pemasarannya. Hakikatnya promosi adalah suatu bentuk komunikasi pemasaran yang dimaksud dengan komunikasi pemasaran adalah aktivitas pemasaran yang berusaha menyebarkan informasi, mempengaruhi/membujuk dan mengingatkan pasar sasaran atas perusahaan dan produknya agar bersedia menerima, membeli dan loyal pada produk yang ditawarkan perusahaan yang bersangkutan (Tjiptono, 2008, hal. 219). Masyarakat menginginkan pemasaran dilakukan dengan cara bagaimana peran pemerintah dalam mempromosikan sebuah produk, door to door, secara online dan personal selling.

\section{Peran Pemasaran Bagi Masyarakat}

1. Peran pemasaran dalam memenuhi kebutuhan dan keinginan manusia

a) Setiap manusia selalu berusaha memenuhi semua kebutuhannya dengan mengkonsumsi produk yang ada.

b) Pemenuhan kebutuhan tersebut dengan melihat manfaat dan kegunaannya.

c) Manfaat atau kegunaan dapat dilihat dari bentuk, tempat, waktu dan kepemlikan. 
d) Fungsi pemasaran juga mempunyai peranan yang sangat penting dalam menigkatkan daya guna suatu barang, yang tadinya kurang berarti di suatu tempat dan akan menjadi tinggi nilainya di tempat lain.

e) Dengan meningkatnya daya guna suatu barang, maka secara otomatis akan memenuhi kebutuhan dan keinginan manusia terhadap produk/ barang terebut.

f) Di era modern ini dengan semakin tingginya taraf hidup sosial suatu masyarakat maka semakin banyak tingkat pilihan masyarakat dalam memenuhi kebutuhannya.

g) Pemasaran sangat dibutuhkan agar masyarakat dapat mengetahui dan mengenali berbagai macam produk sejenis dan tentunya dengan manfaatnya masing-masing.

2. Peranan pemasaran dalam mengalirkannya produk dari produsen ke konsumen

a) Pada dasarnya kegiatan pemasaran menyangkut 2 hal, yaitu aliran fisik barang dan aliran kegiatan transaksi barang tersebut.

b) Aliran transaksi dimulai dari penjualan barang dari pabrik kepada pedagang besar, kemudian dari pedagang besar dijual kepada agen, dari agen dijual kembali kepada toko-toko di pasar dan akhirnya kepada konsumen

c) Dari kegiatan tersebut banyak pihak yang berperan, yaitu sektor transportasi, jasa sewa gudang dan pihak perbankan maupun asuransi.

\section{Masyarakat}

Masyarakat adalah sekumpulan individu-individu yang hidup bersama, bekerja sama untuk memperoleh kepentingan bersama yang telah memiliki tatanan kehidupan, norma-norma, dan adat istiadat yang ditaati dalam lingkungannya. Masyarakat berasal dari bahasa inggris yaitu "society" yang berarti "masyarakat", lalu kata society berasal dari bahasa latin yaitu "societas" yang berarti "kawan". Sedangkan masyarakat yang berasal dari bahasa arab yaitu "musyarak". Pengertian masyarakat terbagi atas dua yaitu pengertian masyarakat dalam arti luas dan pengertian masyarakat dalam arti sempit. Pengertian Masyarakat dalam Arti Luas adalah keseluruhan hubungan hidup bersama tanpa dengan dibatasi lingkungan, bangsa dan sebagainya. Sedangkan pengertian masyarakat dalam arti sempit adalah sekelompok individu yang dibatasi oleh golongan, bangsa, teritorial, dan lain sebagainya. Pengertian masyarakat juga dapat didefinisikan sebagai kelompok orang yang terorganisasi karena memiliki tujuan yang sama. Pengertian Masyarakat secara Sederhana adalah sekumpulan manusia yang saling berinteraksi atau bergaul dengan kepentingan yang sama. Terbentuknya masyarakat karena manusia menggunakan perasaan, pikiran dan keinginannya memberikan reaksi dalam lingkungannya.

Selain rumah tangga keluarga, masyarakat juga merupakan salah satu dari pelaku ekonomi. Masyarakat merupakan kumpulan dari rumah tangga. Masyarakat sebagai pelaku ekonomi sama seperti rumah tangga, yakni berperan 
sebagai podusen, distributor dan konsumen. Untuk penjelasan lebih lanjut, akan dijelaskan satu per satu.

a. Masyarakat sebagai Produsen

Masyarakat sebagai produsen mencakup berbagai bentuk kegiatan masyarakat yang dapat menghasilkan pendapatan, misalnya dapat berupa kegiatan usaha, berdagang, bercocok tanam, beternak, dan sebagainya.

Sistem ekonomi Indonesia memiliki acuan yang jelas, yaitu UndangUndang Dasar 1945. Maka dari itu sistem ekonomi bukanlah pasar bebas maupun perencanaan sentral, melainkan sistem ekonomi Indonesia mendasarkan pada ekonomi kerakyatan. Dalam sistem ekonomi kerakyatan masyarakat memegang peranan aktif dalam kegiatan ekonomi, sedangkan pemerintah menciptakan iklim yang sehat bagi pertumbuhan dan perkembangan dunia usaha.

Sistem ekonomi kerakyatan dapat didefinisikan sebagai pengaturan kehidupan ekonomi yang memungkinkan seluruh potensi masyarakat untuk berpartisipasi aktif dalam berbagai kegiatan ekonomi. Kesejahteraan rakyat yang meningkat, merata, dan berkeadilan merupakan tujuan utama demokrasi ekonomi kerakyatan.

Salah satu pilar penyangga ekonomi kerakyatan adalah usaha informal yang berkembang dalah kehidupan masyarakat. Ciri-ciri sektor usaha informal adalah sebagai berikut:

1) Sektor usaha informal tidak memiliki alat-alat produksi yang canggih.

2) Pelaku ekonomi sektor usaha informal tidak memiliki pendidikan/keahlian khusus.

3) Sektor usaha informal dapat membuka lapangan kerja yang tidak sedikit jumlahnya.

4) Sektor usaha informal hanya memiliki ruang lingkup usaha ekonomi yang sempit dan kecil.

Beberapa contoh kegiatan ekonomi sektor usaha informal adalah:

1) Pedagang asongan

2) Pedagang sambilan

3) Pedagang kaki lima

4) Pedagang keliling

b. Masyarakat sebagai Konsumen

Masyarakat sebagai konsumen memerlukan barang dan jasa bagi kelangsungan hidup masyarakat. Masyarakat adalah pengguna (konsumen) "public goods" atau produk-produk umum, seperti jalan raya, jembatan, rumah sakit, sekolah, dan lain-lain. Penggunaan public goods yang pada umumnya disediakan oleh pemerintah pusat maupun daerah, bertujuan untuk memenuhi kebutuhan hidupnya.

Masyarakat yang tidak memiliki pekerjaan atau pengangguran merupakan bentuk kehidupan yang hanya melakukan kegiatan konsumsi 
saja, sehingga sering menimbulkan masalah di masyarakat. Berbagai tindak kejahatan dilakukan semata-mata karena untuk memenuhi kegiatan konsumsi. Di mana orang memiliki banyak kebutuhan, tetapi tidak memiliki pekerjaan yang dapat menghasilkan pendapatan bagi pemenuhan kebutuhan tersebut.

Oleh karena itu, penting bagi setiap orang sejak dini tertanam sikap untuk mampu berproduksi dan bukan hanya melakukan konsumsi saja. Di samping itu berkaitan dengan kegiatan konsumsi, perlu dilandasi sikap mental untuk bisa mengukur kemampuan diri, sehingga tidak besar pasak daripada tiang.

c. Masyarakat sebagai distributor

Masyarakat sebagai distributor diwujudkan dalam bentuk terjadinya penyaluran proses penyaluran barang dan jasa dari produsen ke konsumen. Lalu lintas perdagangan dan transportasi yang membawa barang-barang pemenuhan kebutuhan dalam kehidupan masyarakat merupakan bentuk kegiatan distribusi yang berlangsung di masyarakat.

Kelancaran arus distribusi yang berlangsung di masyarakat dapat kita amati dari lancar-tidaknya proses transportasi barang kebutuhan dari satu kota ke kota yang lain. Salah satu faktor yang memicu terjadinya kelangkaan barang antara lain disebabkan ketidaklancaran proses distribusi. Hal ini sering terjadi di daerah-daerah yang sulit transportasinya.

\section{METODE PENELITIAN}

Metode penelitian yang digunakan adalah metode kualitatif. Sesuai dengan fokus penelitian, maka untuk mendapatkan data peran pemasaran sumber datanya diperoleh dari informan melalui angket dan wawancara. Dalam penelitian ini instrumen penelitian yang utama adalah peneliti sendiri, namun setelah fokus penelitian menjadi jelas maka dikembangkan instrumen penelitian sederhana yang dapat mempertajam serta melengkapi data hasil pengamatan dan observasi. Instrumen yang digunakan adalah bauran marketing mix melalui penyebaran angket.

Teknik analisis data yang digunakan dalam penelitian ini adalah analisis data kualitatif, mengikuti konsep yang diberikan Miles and Huberman dan Spradley. Miles dan Huberman (1984) dalam Sugiyono (Sugiyono, 2013, hal. 207), mengemukakan bahwa aktivitas dalam analisis data kualitatif dilakukan secara interaktif dan berlangsung secara terus menerus pada setiap tahapan penelitian sehingga sampai tuntas, dan datanya sampai jenuh. Aktivitas dalam analisis data, yaitu data reduction, data display, dan conclusion drawing/verification.

Selanjutnya menurut Spradley dalam Sugiyono (Sugiyono, 2013, hal. 208), teknik analisis data disesuaikan dengan tahapan dalam penelitian. Pada tahap penjelajahan dengan teknik pengumpulan data grand tour question, analisis data dilakukan dengan analisis domain. Pada tahap menentukan fokus analisis data dilakukan dengan analisis taksonomi. Pada tahap selection, analisis data dilakukan 
dengan analisis komponensial. Selanjutnya untuk sampai menghasilkan judul dilakukan dengan analisis tema. Analisis data model Miles and Huberman, yang meliputi data reduction, data display, dan conclusion drawing/verification dilakukan pada setiap tahapan penelitian menurut Spradley (penjelajahan, fokus, dan selection).

\section{HASIL DAN PEMBAHASAN}

Untuk mengetahui bagaimana peran pemasaran dalam Kegiatan Usaha pada Masyarakat di Desa Jatibaru, Cikampek, maka dilakukan analisis melalui bauran mix (Productt, Price, Place, Promotion).

Tabel 1

Data Penelitian

\begin{tabular}{|c|c|c|c|c|c|c|}
\hline \multirow{2}{*}{ NO } & \multirow{2}{*}{ KETERANGAN } & \multicolumn{5}{|c|}{ SKALA LIKERT } \\
\hline & & SS & $\mathbf{S}$ & KS & TS & STS \\
\hline \multirow[t]{6}{*}{1} & PRODUCTT & & & & & \\
\hline & 1. Kebutuhan & $93,33 \%$ & $6,67 \%$ & & & \\
\hline & 2. Kualitas & $93,33 \%$ & $6,67 \%$ & & & \\
\hline & 3. Desain & $80 \%$ & $20 \%$ & & & \\
\hline & 4. Ramah Lingkungan & $66,67 \%$ & $33,33 \%$ & & & \\
\hline & 5. Mudah diingat & $70 \%$ & $30 \%$ & & & \\
\hline \multirow[t]{4}{*}{2} & PRICE & & & & & \\
\hline & 1. Sesuai dengan Kualitas & $63,33 \%$ & $36,67 \%$ & & & \\
\hline & 2. Terjangkau Masyarakat & $56,67 \%$ & $43,33 \%$ & & & \\
\hline & 3. Bersaing & $66,67 \%$ & $33,33 \%$ & & & \\
\hline \multirow[t]{4}{*}{3} & PLACE & & & & & \\
\hline & 1. Mudah didapatkan & $60 \%$ & $40 \%$ & & & \\
\hline & 2. Mudah diakses & $53,33 \%$ & $46,67 \%$ & & & \\
\hline & 3. Jangkauan terbatas & $56,67 \%$ & $40 \%$ & & $3,33 \%$ & \\
\hline \multirow[t]{5}{*}{4} & PROMOTION & & & & & \\
\hline & 1. Peran Pemerintah & $10 \%$ & $66,67 \%$ & $23,33 \%$ & & \\
\hline & 2. Face to face & $46,67 \%$ & $53,33 \%$ & & & \\
\hline & 3. Online & & $46.67 \%$ & $53,33 \%$ & & \\
\hline & 4. Personal Selling & & $43,33 \%$ & $56,67 \%$ & & \\
\hline
\end{tabular}

Hasil analisis menunjukkan bahwa bauran mix dalam pemasaran dapat menentukan Kegiatan Usaha pada Masyarakat di Desa Jatibaru, Cikampek.

1. Ditinjau dari segi produk (product), bahwa produk yang dinginkan masyarakat adalah produk yang sesuai kebutuhan masyarakat, berkualitas, memiliki desain yang menarik, produk yang dihasilkan ramah lingkungan, dan mudah diingat masyarakat.

a. $\quad$ Produk yang sesuai kebutuhan masyarakat menunjukkan 93,33\% (28 responden) menyatakan setuju dan $6,67 \%$ ( 2 responden) menyatakan 
setuju. Hal ini menandakan jika ingin menciptakan suatu produk harus melihat apa yang sedang dibutuhkan masyarakat.

b. Produk yang berkualitas menunjukkan 93,33\% (28 responden) menyatakan setuju dan $6,67 \%$ (2 responden) menyatakan setuju. Hal ini menunjukkan masyarakat menginginkan produk yang berkualitas.

c. Desain produk menunjukkan $80 \%$ (24 responden) menyatakan sangat setuju dan 20\% (6 responden) menyatakan setuju. Masyarakat menginginkan produk yang dihasilkan memilik desain yang menarik.

d. Produk yang ramah lingkungan menunjukkan $66,67 \%$ (20 responden) menyatakan sangat setuju dan 33,33\% (10 responden) menyatakan setuju. Masyarakat mengingkan bahwa pruduk yang dibeli ramah lingkungan.

e. Produk mudah diingat menunjukkan $70 \%$ (21 responden) menyatakan sangat setuju dan 30\% (9 responden) menyatakan setuju. Produk yang mudah diingat akan memberikan kesan tersendiri bagi masyarakat.

Hasil penelitian ini mendukung hasil penelitian N.Chamhuri dan P.J Batt (Chamhuri \& P, 2009, hal. 11) yang menyatakan bahwa "ketersediaan dan variasi produk mempengaruhi keputusan pembelian konsumen". Pendapat Levy \& Weitz (Levy \& Weitz, 2009, hal. 112) juga menyatakan bahwa "persediaan barang mempunyai pengaruh terhadap keputusan pembelian ulang konsumen". Penelitian (Karnawati \& Hamzah, 2008) juga menunjukkan bahwa variabel desain dan tampilan toko secara signifikan mempengaruhi keputusan pembelian konsumen.

Sejalan dengan penelitian yang dilakukan Christian A.D Selang (Selang, 2013, hal. 78), hasil penelitian menunjukan bahwa produk berpengaruh terhadap Loyalitas Konsumen mengenai Intensitas kompetisi di pasar memaksa perusahaan untuk mengupayakan adaptasi produk yang tinggi guna meraih keunggulan yang kompetitif atas pesaing, karena adaptasi produk dapat memperluas basis pasar lokal dan ditingkatkan untuk preferensi lokal tertentu. Konsumen semakin banyak memiliki alternatif dan sangat hati-hati dalam menentukan keputusan untuk melakukan pembelian dengan mempertimbangkan faktor-faktor kebutuhan, keunggulan produk, pelayanan dan perbandingan harga sebelum memutuskan untuk membeli (Tjiptono, 2008). Secara perusahan telah memiliki berbagai produk yang baik pada aspek kelengkapan produk, merek produk, ukuran produk dan kualitas produk,. Kelengkapan produk telah menyediakan keragaman produk secara lengkap, Hal ini ditunjukkan dari tersedianya produk peralatan rumah tangga, produk pakaian, produk makanan dan minuman, produk peralatan tulis, serta tersedianya produk-produk supermarket seperti bahan makanan dan sayursayuran, sabun, sampo, kosmetik, dan lain-lain. Ditinjau dari aspek merek produk telah menyediakan merek produk secara baik, Hal ini ditunjukkan dari tersedianya produk-produk sejenis dengan berbagai merek seperti produk sabun dan sampo, kosmetik, dan lain-lain. Ditinjau dari aspek ukuran produk telah menyediakan ukuran produk dengan baik. Hal ini ditunjukkan dari tersedianya produk-produk yang memiliki berbagai ukuran seperti sampo, sepatu, susu, sabun, dan lain-lain. 
2. Ditinjau dari segi harga (price), masyarakat menginginkan harga yang sesuai dengan kualitas, tejangkau setiap lapisan masyarakat, dan harga mampu bersaing.

a. Harga sesuai dengan kualitas menunjukkan 63,33\% (19 responden) menyatakan sangan setuju dan $36,67 \%$ (11 responden) menyatakan setuju. Hal ini menyatakan bahwa masyarakat akan membeli suatu produk berdasarkan harga dan kualitas. Harga mahal asalkan kualitas baik.

b. Harga yang terjangkau setiap lapisan masyarakat menunjukkan $56,67 \%$ (17 responden) menyatakan sangat setuju dan 43,33\% (13 responden) menyatakan setuju.

c. Harga mampu bersaing dengan pasar global menunjukkan $66,67 \%$ (20 responden) menyatakan sangat setuju dan 33,33\% (10 responden) menyatakan setuju.

Hal ini sejalan dengan pendapat Levy \& Weitz (Levy \& Weitz, 2009, hal. 112) yang menyatakan bahwa "harga mempengaruhi konsumen untuk melakukan pembelian ulang". Hasil penelitian Karnawati dan Hamzah (Karnawati \& Hamzah, 2008, hal. 44), juga menemukan bahwa "harga mempengaruhi keputusan pembelian konsumen".

Sejalan dengan penelitian yang dilakukan Christian A.D Selang (Selang, 2013, hal. 79). Hasil penelitian menunjukan bahwa harga berpengaruh terhadap Loyalitas Konsumen, bahwa perusahaan mengadakan pendekatan terhadap penentuan harga berdasarkan tujuan yang hendak dicapainya. Adapun tujuan tersebut dapat berupa meningkatkan penjualan, mempertahankan market share, mempertahankan stabilitas harga, mencapai laba maksimum dan sebagainya. Berdasarkan hasil penelitian di lapangan dapat dilihat bahwa harga produk yang ditawarkan, harga produk yang ditawarkan freshmart sesuai dengan kualitas. Produk dengan kualitas baik. Hal ini ditunjukkan dari tersedianya produk-produk yang berkualitas sesuai dengan standart kualitas yang diinginkan oleh konsumen, dan harga produk yang ditawarkan sesuai dengan manfaat, sehingga konsumen lebih memilih tempat berbelanja, konsumen selalu merekomendasikan hal -hal yang baik tentang dan konsumen merasa senang jika berbelanja (Tjiptono, 2008).

3. Ditinjau dari tempat (place) masyarakat menginginkan produk yang akan dibeli mudah didaptkan, mudah diakses, jangkauan tempat terbatas.

a. Tempat (place) yang mudah didapatkan menunjukan 60\% (18 responden) menyatakan sangat setuju dan $40 \%$ (12 responden) menyatakan setuju.

b. Tempat (place) yang mudah diakses menunjukan 53,33\% (16 responden) menyatakan sangat setuju dan 4,67\% (14 responden) menyatakan setuju.

c. Tempat (place)yang memiliki jangkauan yang terbatas menunjukan $56,67 \%$ (17 responden) menyatakan sangat setuju, 40\% (12 responden) menyatakan setuju dan 3,33\% (1 responden) menyatakan tidak setuju. 
Menurut (Levy \& Weitz, 2009, hal. 112) "lokasi merupakan salah satu faktor yang mempengaruhi keputusan pembelian ulang konsumen". Hal ini sejalan dengan hasil penelitian (Mamuaya, 2008) bahwa "lokasi mempengaruhi keputusan pembelian ulang konsumen".

Sejalan dengan penelitian yang dilakukan Christian A. D Selang (Selang, 2013, hal. 79). Hasil penelitian menunjukan bahwa tempat tidak berpengaruh terhadap Loyalitas Konsumen, hasil ini menyatakan bahwa keputusan pemilihan lokasi berkaitan dengan komitmen jangka panjang terhadap aspek-aspek yang sifatnya kapital intensif, maka perusahaan benar-benar harus mempertimbangkan dan menyeleksi lokasi yang responsif terhadap situasi ekonomi, demografi, budaya, dan persaingan dimasa mendatang. Tempat secara langsung mempengaruhi loyalitas konsumen. Untuk produk sebagai pemuas kebutuhan primer akan menentukan pilihan konsumen terhadap produk tersebut. Sebuah produk tidak akan banyak gunanya bagi seorang pembeli apabila produk yang ditawarkan tersebut tidak tersedia pada saat dan tempat yang tepat dimana konsumen memerlukannya (Tjiptono, 2008).

4. Ditinjau dari promosi, masyarakat menginginkan pemasaran dilakukan dengan cara bagaimana peran pemerintah dalam mempromosikan sebuah produk, door to door, secara online dan personal selling.

a. Promosi yang dilakukan dengan peran pemerintah menunjukan $10 \%$ ( 3 responden) menyatakan sangat setuju, 66,67\% (20 responden) menyatakan setuju, 23,33\% (7 responden) menyatakan kurang setuju.

b. Promosi yang dilakukan dengan cara door to door menunjukan 46,67\% (14 responden) menyatakan sangat setuju, dan 53,33\% (16 responden) menyatakan seetuju.

c. Promosi yang dilakukan dengan cara online menunjukan $46,67 \%$ (14 responden) menyatakan setuju, dan 53,3\% (16 responden) menyatakan kurang setuju.

d. Promosi yang dilakukan dengan cara personal selling menunjukan 43,33\% (13 responden) menyatakan kurang setuju, dan 56,67\% (17 responden) menyatakan kurang setuju.

Sejalan dengan penelitian yang dilakukan Christian A.D Selang (Selang, 2013, hal. 79) hasil ini menyatakan bahwa promosi merupakan suatu kegiatan yang sangat penting untuk dilaksanakan dalam pemasar produk. Melalui kegiatan promotion mix ini, perusahaan berusaha untuk memberitahukan kepada konsumenmengenai suatu produk dan mendorong untuk membeli produk tersebut. Banyak cara yang dilakukan olehperusahaan untuk mempromosikan produknya. Promosi merupakan kegiatan yang ditujukan untuk mempengaruhi konsumen agar mereka dapat mengenali akan produk yang ditawarkan oleh perusahaan kepada mereka dan kemudian mereka menjadi senang lalu membeli produk tersebut. promosi juga merupakan salah satu bagian dari alat pemasaran yang memegang peranan yang cukup penting di dalam meningkatkan volume penjualan barang dan jasa dengan menawarkan kepada masyarakat konsumen. Tujuan utama promosi adalah menginformasikan, mempengaruhi dan membujuk serta mengingatkan pelanggan sasaran tentang pemasaran dan bauran pemasaran. Promosi yang 
dilakukan dengan cara pemberian diskon, brosur yang menarik serta melalui SPG atau karyawan.

\section{E. SIMPULAN}

Berdasarkan hasil penelitian, dapat ditarik simpulan bahwa pemasaran memiliki peran penting dalam menentukan kegiatan usaha pada masyarakat di Desa Jatibaru, Cikampek. Pemasaran disini ditinjau dari sudut pandang bauran pemasaran. Agar usaha dapat berkembang dan berjalan dengan baik sejalan dengan teknologi saat penjualan sekarang dan masa menadatang. Terutama pada penggunan bauran pemasaran agar dapat menentukan pangsa pasar dan dapat mencapai target. Ditinjau dari segi produk (product), bahwa produk yang dinginkan masyarakat adalah produk yang sesuai kebutuhan masyarakat, berkualitas, memiliki desain yang menarik, produk yang dihasilkan ramah lingkungan, dan mudah diingat masyarakat. Ditinjau dari segi harga (price), masyarakat menginginkan harga yang sesuai dengan kualitas, tejangkau setiap lapisan masyarakat, dan harga mampu bersaing. Ditinjau dari tempat (place) masyarakat menginginkan produk yang akan dibeli mudah didapatkan, mudah diakses, jangkauan tempat terbatas. Ditinjau dari promosi, masyarakat menginginkan pemasaran dilakukan dengan cara bagaimana peran pemerintah dalam mempromosikan sebuah produk, door to door, secara online dan personal selling. Dibutukan pula akses internet, maka e-commerce dapat membantu meningkatkan penjualan hingga keseluruh mancanegara. 


\section{DAFTAR PUSTAKA}

Assauri, S. (2011). Manajemen Pemasaran (11 ed.). Jakarta, DKI Jakarta, Indonesia: PT. Raja Grafindo Persada.

Chamhuri, N., \& P, B. J. (2009). Factors Influencing Consumer's Choice of Retail Stores for Fresh Meat in Malaysia. Journal of Marketing and Logistics, 331-348.

Karnawati, T. A., \& Hamzah, L. N. (2008). Analisis Pengariuh Strategi Marketing Mix terhadap Keputusan Pembelian Konsumen Toko Eceran Tradisional Kepanjen Malang. Jurnal Ilmiah Bisnis dan Ekonomi ASIA , 3 (1), 34-46.

Kotler, P., \& Keller, K. L. (2009). Manajemen Pemasaran (13 ed.). (2, Ed., \& B. Sabran, Trans.) Jakarta, DKI Jakarta, Indonesia: Erlangga.

Levy, M., \& Weitz, B. A. (2009). Retailing Management (7 ed.). New York, USA: McGraw-Hill.

Machfoedz. (2005). Pengantar Pemasaran Modern (1 ed.). Yogyakarta, Jawa Tengah, Indonesia: Unit Penerbit dan Percetakan Akademi Manajemen Perusahaan YKPN.

Mamuaya, N. C. (2008). Pengaruh Variabel-Variabel Retail Mix terhadap Keputusan Pembelian Konsumen di Supermarket Kota Manado. Jurnal FORMAS , 2 (1), 29-40.

Molan, B. (2007). Manajemen Pemasaran (Vol. 1). Jakarta, DKI Jakarta, Indonesia: PT. Indeks.

Saladin, D. (2006). Manajemen Pemasaran (4 ed.). Bandung, Jawa Barat, Indonesia: Linda Karya.

Selang, C. A. (2013). Bauran Pemasaran (Marketing Mix) Pengaruhnya terhadap Loyalitas Konsumen pada Fresh Mart Bahu Mall Manado. Jurnal EMBA: Jurnal Riset Ekonomi, Manajemen, Bisnis dan Akuntansi , 1 (2), 71-80.

Tjiptono, F. (2008). Strategi Pemasaran (3 ed.). Yogyakarta, Jawa Tengah, Indonesia: ANDI. 